QAULAN, Vol. 2, No.1, Juni 2021

Himatul Choiroh and Asna Istya Marwantika, Teacher's Corporal.....

\title{
TEACHER'S CORPORAL PUNISHMENT TO STUDENTS AS LEARNING COMMUNICATION AT MAMBAUL HISAN CHILDREN'S ISLAMIC BOARDING SCHOOL PONOROGO
}

\author{
Himatul Choiroh \\ Jurusan Komunikasi dan Penyiaran Islam/IAIN Ponorogo \\ Email: himaa.fadmaa@gmail.com \\ Asna Istya Marwantika \\ Jurusan Komunikasi dan Penyiaran Islam/IAIN Ponorogo \\ Email : marwantika@iainponorogo.ac.id
}

\begin{abstract}
Learning communication is the process of delivering messages from teachers to students. One of the objectives of learning communication is to form a student's disciplinary attitude. The application of discipline sometimes requires corporal punishment as done in Mambaul Hisan Children's Islamic Boarding School Ponorogo. The purpose of this research is to describe the form of corporal punishment of teachers in learning communication at Mambaul Hisan Children's Islamic Boarding School Ponorogo. This research was conducted using descriptive research method with qualitative approach. Data collection techniques in this research are observations, interviews and documentation. Data analysis techniques using George Herbert Mead's symbolic interactionalism theory. The result of this study is the first, the application of corporal punishment in learning communication in Mambaul Hisan in the form of verbal and non verbal communication. Verbal communication is done by the teacher by warning students who make mistakes, nonverbal communication by giving corporal punishment such as being pinched, beaten, or tweaked. Second, the implication of corporal punishment given by teachers to students is a deterrent attitude and so as not repeating their mistakes.
\end{abstract}

Keywords: Corporal Punishment,Llearning Communication, Mambaul Hisan

\section{INTRODUCTION}

Every educational institution has its own rules or regulations to increase student enthusiasm in education. So that anyone who violates it will be subject to sanctions or penalties. Punishment imposed in the world of education must have an educational element and provide a deterrent effect, so that students try to obey the rules in order to avoid the punishment. This regulation or order in the field of education has the aim of being able to shape the character and soul of a student so that it can be useful for the country, nation, and religion. ${ }^{1}$

1 Moh. Zainul Rosyid and Aminol Rosyid Abdullah, Reward Dan Punishment Dalam Pendidikan (Malang: Literasi Nusantara, 2018), 4. 
QAULAN, Vol. 2, No.1, Juni 2021

Himatul Choiroh and Asna Istya Marwantika, Teacher's Corporal.....

In ancient times, teaching using corporal punishment was a common practice in various educational institutions. However, today, teachers do not have the right or are not allowed to physically punish children in the teaching and learning process. ${ }^{2}$ Quoted from the sukabumiupdate.com online news, a teacher was rested for beating a 3rd grade elementary school student who was fighting and making a scene in the classroom with a LKS book. The rest is carried out at the level of request from the guardian of the student who did not accept it because the child was subject to corporal punishment. Even though in the end the teacher is allowed to teach again on the condition that he will not give corporal punishment to the student again. ${ }^{3}$

Mambaul Hisan Children's Islamic Boarding School is located in Kadipaten Village, Babadan, Ponorogo. This Islamic boarding school has been established since year 2002 and branch from Blitar East Java. Mambaul Hisan is a special boarding school for children from kindergarten to 6th grade. Based on observations made by researchers, the educational process still uses educational methods commonly used by teachers in ancient times. For those who break the rules or are difficult to control, they will be punished. In fact, sometimes the caregiver also provides corporal punishment such as being pinched, jeweled, or beaten. Corporal punishment is carried out to teach discipline and responsibility to the students. This is usually experienced by those who have been warned repeatedly but still violate or argue.

This phenomenon will be analyzed using George Herbert Mead's theory of symbolic interactionalism with the aim of knowing how the implementation and implications of teacher corporal punishment in the learning system at the Mambaul Hisan Children's Islamic Boarding School. Interaction is a process that connects the sender of the message with the recipient of the message. The concept of interaction is the key word for understanding the communication process. Because, communication is a means of connecting two or more people through sending and receiving messages and making messages meaningful. ${ }^{4}$ Symbolic interactionism is a communication theory commonly known as SI. Through this theory it can be seen some explanations about the motivation of people to have a conversation, the process of generating meaning through conversation and the emergence of an agreement on a symbol that can be understood through

2 Rega Maradewa, "Disiplinkan Peserta Didik Dengan Hukuman Fisik Wajib Dihentikan," kpai.go.id, 2019, diakses pada 16 November 2020 dilaman https://www.kpai.go.id/berita/disiplinkan-peserta-didikdengan-hukuman-fisik-wajib-dihentikan-.

3 Uploader, "Bertengkar Di Kelas, Guru Pukul Murid Dengan LKS Berujung Islah," radarsukabumi.com, 2020, diakses pada 13 Oktober 2020 dilaman https://radarsukabumi.com/kotasukabumi/bertengkar-di-kelas-guru-pukul-murid-dengan-lks-berujung-islah/.

${ }^{4}$ Liliweri, Komunikasi Serba Ada Dan Serba Makna (Jakarta: Kencana Prenada Media Group, 2011), 64. 
QAULAN, Vol. 2, No.1, Juni 2021

Himatul Choiroh and Asna Istya Marwantika, Teacher's Corporal.....

interaction in conversation. The focus of attention from symbolic interactionalism lies in how humans shape meaning through conversation. ${ }^{5}$

\section{METHODS}

The research in this article is field research (field research) with qualitative research methods applied by collecting data and analyzed using George Herbert Mead's theory of symbolic interactionalism, then interpreted without using statistics. While the data processing technique was carried out through several stages, namely a) conducting observations by involving oneself in learning activities carried out at the Mambaul Hisan Children's Islamic Boarding School, b) Conducting interviews with teachers and students at the Children's Islamic Boarding School. Mambaul Hisan, c) Doing documentation by taking photos of learning activities at the Mambaul Hisan Children's Islamic Boarding School, d) Data analysis using George Herbert Mead's Symbolic Interactionism theory to determine the implementation and implications of teacher corporal punishment in the learning system at the Children's Islamic Boarding School. Mambaul Hisan. The process of analyzing data in this process is by examining all available data from various sources. Next is to reduce the data, then interpret the data or process the data to draw conclusions using George Herbert Mead's theory of symbolic interaction.

\section{CORPORAL PUNISHMENT IN THE LEARNING COMMUNICATION}

Punishment in education has a very broad meaning. Starting from light punishment to heavy punishment. Starting from cues such as a stinging wink to a slightly painful blow in accordance with the limits of the educator to direct students towards the expected behavior. Punishment is suffering that is given intentionally by someone (parents, teachers, etc.) after an error, violation, or crime has occurred. ${ }^{6}$ Punishment is an educational tool that gives suffering to punished students which contains motivation so that students try to improve themselves and fulfill the assignments given to avoid punishment. ${ }^{7}$

Punishment is a form of sanction given to individuals or groups for violations, crimes or mistakes that have been committed in the form of suffering to improve behavior so that it is not repeated in the future. The fear that arises as a result of the punishment given has the benefit of

${ }^{5}$ Morissan, Teori Komunikasi: Individu Hingga Massa (Jakarta: Kencana, 2013), 224.

${ }^{6}$ Ahmad Izzan and Saehudin, Tafsir Pendidikan: Konsep Pendidikan Berbasis Alquran (Bandung: Humaniora, n.d.), 72.

${ }^{7}$ Moh. Zainul Rosyid dan Aminol Rosid Abdullah, Reward Dan Punishment Dalam Pendidikan, 9. 
QAULAN, Vol. 2, No.1, Juni 2021

Himatul Choiroh and Asna Istya Marwantika, Teacher's Corporal.....

inhibiting desires that are negative or not in accordance with the rules. Because if the negative behavior is repeated, it will receive punishment again. Based on the form of action given, punishment is divided into three, namely: a) Presentation punishment is the use of unwelcome or unpleasant consequences, such as yelling, insults, slaps, or students being asked to write "I will not disturb the class.",b) Abolition penalty, namely removing or eliminating the rights of students, such as students being punished standing in front of the class or not allowed to rest during recess., nad 3) Time out is like a student being punished by standing in a corner of the class for violating class rules. The purpose of the punishment is so that the delinquency can be eliminated or for other students to avoid their naughty behavior. ${ }^{8}$

Based on the effect given, punishment is divided into 3 forms, namely:

1. Corporal punishment is a punishment imposed by the offender's body, such as beatings. This punishment is also known as corporal punishment because it has an lasting effect on the body.

2. Feeling punishment is ridicule for students who violate, are humiliated, and cursed at. This punishment does not inflict physical injury, but has an effect on the emotions in the heart of the person being punished.

3. Intellectual punishment, namely the offender is given a punishment in the form of certain activities. This punishment is carried out with the consideration that these activities can lead to improvement. This punishment did not have any negative effects, be it physical injury or emotional injury.

Forms of punishment based on children's development are divided into three levels, namely:

1. Associative punishment, in general humans will associate the offense or crime and the punishment to be given, between the offense committed and the punishment received as a result of the violation. So that children will stay away from offenses or crimes so they don't get punished.

2. Logical punishment is that the child is punished so that he experiences suffering that is logically related to his mistake. This punishment is used on older children who are able to understand the relationship between the mistakes they have committed and the punishment they receive.

3. Moral punishment, namely this level is reached in older children, where children are not only aware of the logical relationship between mistakes and punishment, but are moved by their

${ }^{8}$ Afirah Hartono, "Pengaruh Pemberian Reward Dan Punishment Terhadap Motivasi Belajar Peserta 
QAULAN, Vol. 2, No.1, Juni 2021

Himatul Choiroh and Asna Istya Marwantika, Teacher's Corporal.....

moral feelings or awakened their conscience. He felt that he had to accept punishment as something he had to go through. ${ }^{9}$

\section{SYMBOLIC INTERACTIONALISM THEORY}

The history of the theory of symbolic interactionalism cannot be separated from George Herbert Mead. Mead was born in Hadley, a small town in Massachusetts. Mead's career began with him becoming a professor at the Oberlin campus, Ohio. Then Mead moved teaching from one campus to another. Until finally he was invited by John Dewey to move from the University of Michigan to the University of Chicago. ${ }^{10}$ George Herbert Mead, who is known as the originator of the theory of symbolic interactionalism, greatly admired the human ability to use symbols. Mead said that people will act based on symbolic meanings that arise in certain situations. As the name suggests, this theory of symbolic interactionalism emphasizes between symbols and interactions. Mead rarely published during his educational career, but after his death his students collaborated to create books based on his lecture materials. The book is entitled "Mind, Self, and Society" (Mind, Self, and Society). Interestingly, the term "symbolic interaction" was not created by Mead, but by his pupil, Herbert Blumer. However, Mead was the basis for Herbert Blumer's push to create this theoretical move. blumer published his article on the collection theory of symbolic interactionalism in 1969.11

The basis of symbolic interactions are ideas about individuals and their interactions with society. ${ }^{12}$ These ideas form the meaning that comes from the human mind (mind) about self (self) and their relationship in social interactions which ultimately aims at mediating and interpreting the meaning in the society (society) in which the individual is located. ${ }^{13}$ Mind is a social phenomenon in which the process of conversation with oneself occurs to someone. Thoughts are an integral part of the social processes that arise and develop in these social processes. In this case, thoughts are not interpreted substantively, but functionally. Self is the ability to accept yourself as both a subject and an object. Self arises from social requirements, namely communication between humans. according to Mead, it is impossible for the self to emerge without a social process, but the self has developed.

Didik Kelas V MI AS Adiyah Banua Baru Wonomulyo Polewali Mandar," (Skripsi: UIN Alaudin, 2017), 30-31.

9 Muchlisin Riadi, "Punishment Atau Hukuman (Pengertian, Tujuan, Bentuk, Dan Prinsip)," www.kajianpustaka.com, 2020, https://www.kajianpustaka.com/2020/04/punishment-atau-hukumanpengertian-tujuan-bentuk-dan-prinsip.html?m=1.

${ }^{10}$ Nina Siti Salmaniah Siregar, “Kajian Tentang Interaksionisme Simbolik," Perspektif 1, no. 2 (2016): 101, https://doi.org/10.31289/perspektif.v1i2.86.

11 Richard West dan Lynn H. Turner, Pengantar Teori Komunikasi Analisis Dan Aplikasi, ed. Maria Natalia Damayanti Maer (Jakarta: Salemba Humanika, 2008), 96.

12 Ibid., 55.

${ }^{13}$ Siregar, “Kajian Tentang Interaksionisme Simbolik," 104. 
QAULAN, Vol. 2, No.1, Juni 2021

Himatul Choiroh and Asna Istya Marwantika, Teacher's Corporal.....

Dialectically, the self is related to the mind. One part of the body is not self and will become self when the mind has developed. Self is a social process as well as a mental process, so that self cannot be separated from thoughts.

In Mead's view, society is defined as a social process that takes place without stopping before self and thoughts. In the formation of self and individual thoughts, society has a very important role. The dialectic between self and mind unites and forms actions and behavior according to what is interpreted, this happens in the community. ${ }^{14}$ In its most basic form, social behavior involves a relationship between three parties. The three parties are gestures, responses, and results. The presence of a gesture from a person which is then responded to by the other person will produce results. Outcome is what action means to the communicator. ${ }^{15}$

According to Blumer, in the book Phenomena Teacher Perspectives on Social Identity and Functions written by Mohamad Holis, et al., He stated that there are four basic principles of symbolic interactionalism, namely: First, individuals act based on the meaning of the objects they have. It can be interpreted that the teacher always acts on the basis of the behavior of students in receiving learning at school. Then these actions will be communicated to the guardians of the students which will eventually bring out the functional meaning of the teacher as an educator. Second, interactions between communities will occur in a form of social and cultural dynamics in which physical and social objects (people), as well as situations, must be categorized based on individual meanings. The interaction between teachers and guardians of students is based on their perspective on the teacher in terms of the quality of learning in schools through students. Thus, the guardians of students can interpret the true meaning and function of the teacher according to what the parents feel about the quality of the teacher's attitude in resolving any social conflicts in society. Third, when there is interaction with other people and society, meaning will emerge. The interaction between teachers and students, which will automatically interact with the guardians of students, is a form of searching for original meaning in interpreting teachers in formal education. Fourth, meaning will continue to be created and recreated through the process of interpretation during interactions with other people. The meaning of guardians towards teachers in formal

14 Ali Nurdin, Teori Komunikasi Interpersonal Disertai Contoh Fenomena Praktis (Jakarta: Kencana, 2020), 29.

${ }^{15}$ Morissan, Teori Komunikasi: Individu Hingga Massa, 225-26. 
education will always be dynamic if it is drawn from the concept of function and meaning that should be interpreted into life which later becomes human civilization and culture.16

\section{CORPORAL PUNISHMENT IN THE LEARNING COMMUNICATION AT THE MAMBAUL HISAN CHILDREN'S ISLAMIC BOARDING SCHOOL IN THE PERSPECTIVE OF SYMBOLIC INTERACTION}

A. Implementation of Teacher Corporal punishment in the Learning Communication at Mambaul Hisan Children's Islamic Boarding School

Based on the theory of symbolic interactionalism, the application of corporal punishment at the Mambaul Hisan Children's Islamic Boarding School is grouped into two parts, namely:

1. In accordance with the basic principles of symbolic interactionalism theory which says that individuals act based on the meaning of the objects they have. ${ }^{17}$ From this principle, it can be interpreted that the teachers in this cottage act on the basis of the behavior of the students during the learning process. In this pondok, corporal punishment is applied after the students are warned several times for making mistakes or violating the agreed upon rules in the learning process. ${ }^{18}$ These mistakes and violations, such as the mischievous nature of the students which resulted in quarrels between students ${ }^{19}$, ran away during learning activities, and did not want to participate in learning activities. ${ }^{20}$

2. The most basic form of symbolic interactionalism theory involves three parties, namely gestures, responses, and results. ${ }^{21}$ The first party in implementing corporal punishment as a symbolic interactionalism in this cottage is the teacher who gives a gesture in the form of corporal punishment to the students after giving a warning. The warning is carried out verbally in a low tone first through words, then using a higher tone when the students repeat the mistakes. When the student has been reminded several times, but he still makes the mistake again, then corporal punishment is applied by the teacher.

Arka said, "He was (beaten) twice. Because I didn't memorize it and it was justified but I couldn't. I've been told to memorize a few days and still haven't memorized it."22 Based on Arka's statement, it can be seen that there is a first party from the basic form of symbolic

16 Mohammad Holis and Dkk, Fenomena Guru Perspektif Fungsi Dan Identitas Sosial (Surabaya: Jakad Media Publishing, n.d.), 38-39.

17 Ibid., 38.

${ }^{18}$ Hasil wawancara dengan Eni Masrusoh pada tanggal 18 Desember 2020.

${ }^{19}$ Hasil wawancara dengan Fadhilah santri kelas TK B pada tanggal 16 Desember 2020.

${ }^{20}$ Hasil wawancara dengan Raihan santri kelas TK A pada tanggal 12 Desember 2020.

${ }^{21}$ Morissan, Teori Komunikasi: Individu Hingga Massa, 225. 
interactionalism. The basic form of symbolic interactionalism contained in Arka's statement is in the form of body gestures or gestures given by the teacher. In this case the bodily gesture given by the teacher is corporal punishment. The corporal punishment was in the form of beatings which, according to Arka, he received twice as a consequence he had to accept for repeating mistakes and ignoring warnings from the teacher.

Based on the type of corporal punishment, the corporal punishment applied at the Mambaul Hisan Children's Islamic Boarding School is categorized into three parts, namely:

1. Presentation Punishment.

"The usual punishment is given by giving advance warning. Be warned slowly first, if you can't, then with a slightly high tone, and if you're still using it physically." 23 This was said by the leader of the Mambaul Hisan Children's Islamic Boarding School, Ibu Eni Masruroh. Based on the punitive action applied in the Pondok is a form of presentation punishment. Presentation punishment is a consequence for students who violate the agreed rules or make mistakes by giving them an unwelcome or unpleasant punishment. The punishment was in the form of yelling or warning using a high tone to the students. If you still repeat the mistake again, you will be subject to corporal punishment, such as being pinched, beaten, and jewed. As stated by Ms. Nurjannah, "The punishment is pinching, beating, or twisting her ears." 24

This was confirmed by several expressions of the students by saying, "Once, (beaten) twice" said Arka. ${ }^{25}$ Based on Arka's expression, it can be seen that there was a presentation penalty imposed on him. Presentation penalties are the use of unwelcome or unpleasant consequences, such as yelling, insults, slaps or students being asked to write "I will not disturb the class". ${ }^{26}$ The presentation penalty was in the form of two blows to his body. The punishment in the form of a blow was a form of consequence that had to be accepted by Arka because he had been warned beforehand to memorize the prayer readings, but he still had not memorized it. In addition, Fadhilah also said that she had been pinched by the teacher who taught her. ${ }^{27}$ The punishment given to Fadhilah in the form of a pinch is a form of presentation punishment applied at this Pondok. The pinch given was a form of unpleasant

22 Hasil wawancara dengan Arka santri kelas 2 MI pada tanggal 20 Desember 2020.

${ }^{23}$ Hasil wawancara dengan Ibu Eni Masruroh pada tanggal 18 Desember 2020.

${ }^{24}$ Hasil wawancara dengan Ibu Nurjannah pada tanggal 16 Januari 2021.

${ }^{25}$ Hasil wawancara dengan Arka santri kelas 2 MI 20 Desember 2020.

${ }^{26}$ Hartono, "Pengaruh Pemberian Reward Dan Punishment Terhadap Motivasi Belajar Peserta Didik Kelas V MI AS Adiyah Banua Baru Wonomulyo Polewali Mandar,", 30. 
consequence that had to be accepted by Fadhilah because she did not want to recite the Koran and disturbed her friend who was reciting the Koran.

2. Corporal Punishment

Apart from being a presentation punishment, corporal punishment in the form of pinching, jeweran, and beating, is also a corporal punishment. This is because the punishment is imposed on the body or body of the student who commits the offense. This punishment gives pain to the students who receive it. Raihan said, "Have been (subjected to corporal punishment), often pinched, in the abdomen, thighs, or arms. For not reciting the Koran "28Based on the expression said by Raihan, it can be seen that there is one punishment based on the effect given, namely corporal punishment. Corporal punishment is a punishment imposed by the offender's body, such as beatings. ${ }^{29}$ This corporal punishment certainly has a painful effect on the students. Based on the data that has been obtained, it is known that punishment is imposed on the santri body who commits an offense, so that it can also be said to be a corporal punishment. The punishment was applied to any part of the body or body, usually the abdomen, thighs or arms.

3. Associative Punishment

As participants who make observations by involving themselves in the activities carried out by the people being observed, the researcher has made an agreement with the students. This agreement was made as a final warning to students who often repeat mistakes. This agreement made is like the phrase "If you repeat the mistake again, then I will be subject to corporal punishment". ${ }^{30}$ From this, it can be seen that there is one form of punishment based on child development, namely associative punishment, in general humans will associate the violation or crime and the punishment to be given, between the offense committed and the punishment received as a result of the violation. So that children will stay away from offenses or crimes so they don't get punished. ${ }^{31}$

B. Implications of Teacher Corporal punishment in the Learning System in Mambaul Hisan Children's Islamic Boarding Schools Perspective of Symbolic Interactionism

\footnotetext{
${ }^{27}$ Hasil wawancara dengan Fadhilah santri kelas TK B pada tanggal 16 Desember 2020.

${ }^{28}$ Hasil wawancara dengan Raihan santri kelas TK A pada tanggal 12 Desember 2020.

${ }^{29}$ Riadi, "Punishment Atau Hukuman (Pengertian, Tujuan, Bentuk, Dan Prinsip),"

${ }^{30}$ Hasil observasi

31 Riadi, "Punishment Atau Hukuman (Pengertian, Tujuan, Bentuk, Dan Prinsip)."
} 
Based on the theory of symbolic interactionalism, the implications of corporal punishment in the learning system at the Mambaul Hisan Children's Islamic Boarding School are in accordance with two of the four basic principles of symbolic interaction, namely:

1. Interaction between communities will occur in a particular form of social and cultural dynamics in which physical and social objects (people), as well as situations, must be categorized based on individual meanings. ${ }^{32}$ The occurrence of corporal punishment carried out by the teacher against the students is based on how the students behave during the learning process with the agreement that has been made. Santri who violate the agreement and do not heed the warning given by the teacher, will be subject to corporal punishment. By being subjected to corporal punishment, the violating students want to participate in learning activities (reciting the Koran). ${ }^{33}$

Because corporal punishment is only applied and continues to be applied to students who make mistakes, this is where the meaning that every santri is punished is that they understand that they are doing something wrong.

2. Meaning will emerge when there is interaction with other people and society. ${ }^{34}$ The interaction between the teacher and the students who are subject to corporal punishment will automatically create meaning for other students who are not subject to corporal punishment. Through this interaction, students who are not subject to punishment can understand that the meaning of corporal punishment is the result of mistakes made by the students who are subject to punishment. So, these students try to obey the agreed rules so that they are not subject to corporal punishment. ${ }^{35}$

Based on the most basic form of symbolic interactionalism theory, implications include second and third parties, namely responses and results. ${ }^{36}$ Santri will respond or respond when subjected to corporal punishment by their teacher. From these responses, results will appear in the form of meaning for the corporal punishment received by the students. The responses given by the students when subjected to corporal punishment varied greatly, including:

1. The student is silent because he knows and understands that he made a mistake. Then make changes by doing activities that should be done, such as reciting or memorizing.

\footnotetext{
32 Holis, dkk., Fenomena Guru Perspektif Fungsi Dan Identitas Sosial, 38.

33 Hasil wawancara dengan Eni Masturoh pada tanggal 18 Desember 2020.

${ }^{34}$ Holis and Dkk, Fenomena Guru Perspektif Fungsi Dan Identitas Sosial, 39.

35 Hasil wawancara dengan David santri kelas 3 MI pada tanggal 25 Desember 2020.

36 Morissan, Teori Komunikasi: Individu Hingga Massa, 225.
} 
QAULAN, Vol. 2, No.1, Juni 2021

Himatul Choiroh and Asna Istya Marwantika, Teacher's Corporal.....

2. The student answers in self-defense, but after being given understanding he admits his mistakes and emotionally he feels guilty or sorry. Then want to apologize for making mistakes, such as fighting with other students, mischief which then results in quarrels, and so on.

3. The student are silent, but they only know and understand their mistakes or the students only feel emotionally guilty and sorry. However, this was felt by the santri without any change in him.

Based on the corporal punishment, it can be seen that the santri responded to corporal punishment by silently or replied to defend himself. The result of this corporal punishment is the achievement of one meaning of corporal punishment, namely the santri committing mistakes. However, the changes did not occur entirely in the students. There are students who understand the mistakes they have made and feel guilty or sorry, then make changes. There are also students who only understand their mistakes or just feel guilty and sorry for their mistakes, without making any changes. Most of the changes made by the santri were only temporary. So that the teacher must continuously remember the students to behave in accordance with the norms and agreements that have been made.

Based on the exposure to the data listed in chapter three, it can be seen that the form of punishment given to students also looks at children's development. Forms of punishment based on child development can be divided into three levels, namely:

1. Associative punishment, in general humans will associate the violation or crime and the punishment to be given, between the offense committed and the punishment received as a result of the violation. ${ }^{37}$ So that children will stay away from offenses or crimes so they don't get punished. Apart from associating or making agreements directly about the violations and punishments that will be given to students, teachers can also convey it indirectly. This can happen when the teacher admonishes the students in front of other students. By giving a warning in front of the other students, the teacher indirectly informs the other students about the violations and punishments that will be given. Even though it was conveyed indirectly, the students could understand and stay away from violations so as not to get punished. This was revealed by one of the students, namely David after he saw his friend being punished. He said,

${ }^{37}$ Riadi, "Punishment Atau Hukuman (Pengertian, Tujuan, Bentuk, Dan Prinsip)." 
"(I felt) afraid, I didn't want to be punished like him (the students who were being punished). So, I recited and memorized."38

2. Logical punishment is that the child is punished so that he experiences suffering that is logically related to his mistakes. This punishment is used on older children who are able to understand the relationship between the mistakes they have committed and the punishment they receive. ${ }^{39}$ Most of the students were able to understand the punishment between the mistakes they made and the punishment they received. From this understanding, the students know what violations they have committed so that they are subject to punishment. This logical punishment can be seen from the statements made by the students by knowing and stating the reasons why they were subjected to corporal punishment. One of these statements was expressed by one of the students named Fadil, "I was punished (subjected to corporal punishment) because I did not recite the Koran, disturbed my friends who were reading the Koran". 40

3. Moral punishment, namely this level is reached in older children, where the child is not only aware of the logical relationship between mistakes and punishment, but is moved by feelings of morality or awakens his conscience. He felt that he had to accept punishment as something he had to go through. ${ }^{41}$ One student named David said that he was afraid when he found out that his friend who made a mistake was subject to punishment. He said that he didn't want to do anything wrong so as not to get punished. Because he felt that if he made a mistake then he must accept punishment as a consequence of the mistake he did. ${ }^{42}$ From the statement made by David, it can be seen that there has been moral punishment involved in it. This moral punishment can be seen from the sense of decency of the students who feel they must accept punishment when they make a mistake.

\section{CONCLUSION}

This paper discusses the corporal punishment of teachers in the learning communication at the Mambaul Hisan Children's Islamic Boarding School with the perspective of Symbolic Interactionism theory. From the analysis obtained first, corporal punishment is applied by the teacher after warning the students who have made a mistake. Corporal punishment is given such as being pinched, beaten, or sneaked. Second, the implication of the corporal punishment given by the

\footnotetext{
${ }^{38}$ Hasil wawancara dengan David santri kelas 3 MI pada tanggal 25 Desember 2020.

${ }^{39}$ Riadi, "Punishment Atau Hukuman (Pengertian, Tujuan, Bentuk, Dan Prinsip)."

${ }^{40}$ Hasil wawancara dengan Fadilah santri kelas TK B pada tanggal 16 Desember 2020.

41 Riadi, "Punishment Atau Hukuman (Pengertian, Tujuan, Bentuk, Dan Prinsip)."

42 Hasil wawancara dengan David santri kelas 3 MI pada tanggal 25 Desember 2020.
} 
QAULAN, Vol. 2, No.1, Juni 2021

Himatul Choiroh and Asna Istya Marwantika, Teacher's Corporal.....

teacher to students who make mistakes is that the students are deterred so they do not want to repeat their mistakes again. Meanwhile, for students who are not subject to punishment, they try not to make mistakes in order to avoid corporal punishment.

\section{REFERENCES}

Hartono, Afirah. "Pengaruh Pemberian Reward Dan Punishment Terhadap Motivasi Belajar Peserta Didik Kelas V MI AS Adiyah Banua Baru Wonomulyo Polewali Mandar.” UIN Alaudin, 2017.

Holis, Mohammad, and Dkk. Fenomena Guru Perspektif Fungsi Dan Identitas Sosial. Surabaya: Jakad Media Publishing, n.d.

Izzan, Ahmad, and Saehudin. Tafsir Pendidikan: Konsep Pendidikan Berbasis Alquran. Bandung: Humaniora, n.d.

Liliweri. Komunikasi Serba Ada Dan Serba Makna. Jakarta: Kencana Prenada Media Group, 2011.

Maradewa, Rega. "Disiplinkan Peserta Didik Dengan Hukuman Fisik Wajib Dihentikan.” kpai.go.id, 2019. https://www.kpai.go.id/berita/disiplinkan-peserta-didik-denganhukuman-fisik-wajib-dihentikan-.

Morissan. Teori Komunikasi: Individu Hingga Massa. Jakarta: Kencana, 2013.

Nurdin, Ali. Teori Komunikasi Interpersonal Disertai Contoh Fenomena Praktis. Jakarta: Kencana, 2020.

Riadi, Muchlisin. "Punishment Atau Hukuman (Pengertian, Tujuan, Bentuk, Dan Prinsip).” www.kajianpustaka.com, 2020.

https://www.kajianpustaka.com/2020/04/punishment-atau-hukuman-pengertiantujuan-bentuk-dan-prinsip.html?m=1.

Rosyid, Moh. Zainul, and Aminol Rosyid Abdullah. Reward Dan Punishment Dalam Pendidikan. Malang: Literasi Nusantara, 2018.

Siregar, Nina Siti Salmaniah. "Kajian Tentang Interaksionisme Simbolik.” Perspektif 1, no. 2 (2016): 100-110. https://doi.org/10.31289/perspektif.v1i2.86.

Uploader. "Bertengkar Di Kelas, Guru Pukul Murid Dengan LKS Berujung Islah." radarsukabumi.com, 2020. https://radarsukabumi.com/kota-sukabumi/bertengkardi-kelas-guru-pukul-murid-dengan-lks-berujung-islah/.

West, Richard, and Lynn H. Turner. Pengantar Teori Komunikasi Analisis Dan Aplikasi. Edited by Maria Natalia Damayanti Maer. Jakarta: Salemba Humanika, 2008. 
QAULAN, Vol. 2, No.1, Juni 2021

Himatul Choiroh and Asna Istya Marwantika, Teacher's Corporal.... 